\title{
Ekstrak daun salaon (Indigofera tinctoria $L$ ) sebagai pewarna alami ulos dalam upaya pelestarian kearifan lokal budaya batak
}

\section{The extract salaon (Indigofera tinctoria $L$ ) leaf as the natural dye of ulos in keeping for the batak culture values}

\author{
Jelita Gultom $^{1^{*}}$; Midun Siagian ${ }^{1}$; Ucok Jhon Royagus Tamba ${ }^{1}$; Jecky Bukit ${ }^{1}$; Murniaty Simorangkir ${ }^{1}$ \\ ${ }^{1}$ Jurusan Kimia, Fakultas Matematika dan Ilmu Pengetahuan Alam, Universitas Negeri Medan, Medan-Indonesia \\ *Korespondensi: jelitagultom56@gmail.com
}

\begin{abstract}
Ulos merupakan kain tenun tradisional etnik Batak. Penggunaan pewarna alami Salaon (Indigofera tinctoria L) membutuhkan waktu lama dan tidak praktis sehingga ditinggalkan oleh pengrajin ulos di Kec Muara, Tapanuli Utara dan beralih ke pewarna kimia. Penelitian ini bertujuan mengetahui perbedaan kualitas benang ulos yang menggunakan pewarna alami pasta ekstrak daun Salaon dengan pewarna kimia. Penelitian ini merupakan penelitian eksperimental menggunakan metode ekstraksi zat warna dengan variable pengamatan uji warna, uji tahan luntur terhadap pencucian dan penyinaran. Hasil penelitian menunjukkan bahwa kualitas benang ulos menggunakan ekstrak daun salaon lebih baik dengan nilai daya tahan luntur pencucian 4 (baik), terhadap penyinaran 4-5 (baik) dibandingkan pewarna kimia ponceau GRB dengan nilai daya tahan luntur pencucian 3-4(cukup), terhadap penyinaran 3-4 (cukup). Hasil identifikasi FTIR menunjukkan pada ekstrak daun salaon terdapat senyawa leuco indigo, sehingga dapat disimpulkan bahwa kualitas benang ulos yang menggunakan pewarna alami pasta ektrak daun salaon lebih baik daripada pewarna kimia.
\end{abstract}

Kata kunci: ulos, Indigofera tinctoria L, pasta, Kec Muara Tapanuli Utara

\begin{abstract}
Ulos is a traditional Batak weaving cloth. The use of natural dyes Salaon (Indigofera tinctoria L) takes a long time and is not practical so left by the craftsmen ulos in Kec.Muara, North Tapanuli and switch to chemical dyes. The purpose of this research is to know the difference of quality of ulos yarn which uses natural dye of extract paste Salaon leaf with chemical dye. This research is an experimental research using dyestuff extraction method with variable of observation of color test, fastness test to washing and irradiation. The results showed that the quality of ulos yarns using salaon leaf extract was better with washfastness value of 4 (good), to 4-5 (good) radiation compared to chemical dye ponceau GRB with 3-4 (sufficient) washing fastness value, to 3-4 radiation (sufficient). The result of FTIR identification showed that there is leuco indigo leaf extract, so it can be concluded that the quality of ulos yarn using natural dye of salaon leaf extract is better than chemical dye.
\end{abstract}

Key words: Ulos, Indigofera tinctoria L, paste, Kec Muara Tapanuli Utara

Ulos adalah kain tenun tradisional khas etnik batak, yang digunakan dalam berbagai upacara adat Batak Toba, baik acara sukacita maupun dukacita. Bahan dasar dari ulos adalah sama yaitu kapas yang dipintal jadi benang, tetapi ulos dapat dibeda-bedakan berdasarkan corak, warna dan nilai serta fungsi ulos (Anonim, 2014). Misalnya ulos "Sibolang" yang berwarna biru khas sering digunakan pada acara kematian, ulos "Ragi Hotang" yang berwarna merah untuk acara pernikahan dan lain-lain.
Kerajinan Ulos merupakan salah satu mata pencaharian masyarakat Batak Toba yang tinggal di daerah sekitar perairan Danau Toba, antara lain desa Bariba ni Aek, Kec. Muara, Kab. Tapanuli Utara. Pengrajin Ulos di daerah tersebut menggunakan pewarna kimia ponceau GRB (hasil identifikasi Laboratorium USU, 2017) dan telah lama meninggalkan penggunaan pewarna alami ekstrak daun salaon (Indigofera tinctoria L) yang berwarna biru untuk Ulos "Sibolang". Peralihan penggunaan pewarna alami ke pewarna kimia 
disebabkan proses penyediaan dan penggunaan pewarna alami salaon membutuhkan waktu yang cukup lama sedangkan pewarna kimia cukup praktis. Menurut Laitonjam \& Wangkheirakpam (2011) fermentasi tiga hari ekstrak air dari daun segar Indigofera tinctoria L dan Strobilanthes flaccidifolius mengandung indikan dan prekursor indigo yang lebih banyak dibanding sampel daun kering dan semi kering. Lestari (1998) melaporkan jika glukosa indikan dihidrolisis oleh enzim akan menghasilkan indoksil, kemudian jika diokisdasi dengan udara akan menghasilkan indigo biru.

Tanaman salaon banyak terdapat di daerah Kecamatan Muara, Kabupaten Tapanuli Utara, Provinsi Sumatera Utara seperti disajikan pada Gbr 1.
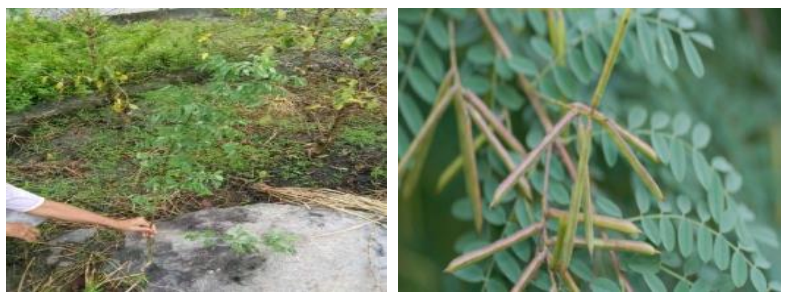

Gbr 1. Salaon (Indigofera tinctoria L)

Hasil determinasi Herbarium Medanense Universitas Sumatera Utara, tanaman salaon adalah:

Kerajaan : Plantae

Divisi : Spermatophyta

Kelas : Dicotyledoneae

Ordo : Fabales

Famili : Fabaceae

Genus : Indigofera

Spesies : Indigofera tinctoria $L$.

Nama Lokal : Salaon.

Menurut Lestari (1998) bahwa proses fermentasi ekstrak daun Salaon dengan penambahan kapur dapat menghasilkan pasta indigo yang digunakan pada pewarnaan batik. Tanaman salaon (Indigofera tinctoria L) dimanfaatkan untuk menghasilkan warna biru dari hasil ekstraksi daun salaon (Kumar et al., 2009). Ekstrak daun salaon mengandung glukosida indikan, yang dapat dihidrolisis menjadi glukosa dan indoksil.

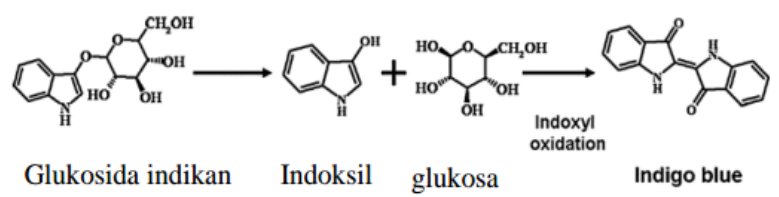

Gbr 2. Reaksi hidrolisis glukosida indikan (Kim et al., 2009)
Indoksil merupakan suatu prekusor (zat pendahulu) yang tak berwarna dari indigo. Indoksil ini dalam suasana alkali mudah teroksidasi oleh udara menjadi pigmen indigo yang berwarna biru. Apabila kain tekstil direndam (dicelupkan) dalam campuran larutan fermentasi yang mengandung indoksil, kemudian dibiarkan kering di udara maka akan terjadi oksidasi indoksil oleh udara dan menghasilkan indigo yang tidak larut dan berwarna biru (Her \& Eka, 2002).

Berdasarkan uraian di atas, peneliti tertarik melakukan penelitian pembuatan pasta indigo dari tanaman salaon dan membandingkan penggunaannya dengan pewarna kimia sebagai pewarna kain tenun ulos Batak.

Penelitian ini bertujuan untuk mengetahui perbedaan kualitas benang ulos yang menggunakan bahan pewarna alami pasta ekstrak daun Salaon (Indigofera tinctoria L) dengan pewarna kimia (sintesis) ditinjau dari daya tahan luntur terhadap pencucian dan penyinaran.

\section{Metode}

Bahan dan alat

Bahan tanaman yang digunakan adalah daun salaon (Indigofera tinctoria L) segar yang diambil dari Desa Bariba ni Aek, Kec.Muara, Kab. Tapanuli Utara, Provinsi Sumatera Utara. Hasil determinasi Herbarium Medanense Universitas Sumatera Utara (Juni, 2017), tanaman salaon adalah Indigofera tinctoria $L$ termasuk family Fabaceae. Bahan kimia yang digunakan adalah bahan pro analysis (p.a) (merck) $\mathrm{HCl}, \mathrm{H}_{2} \mathrm{SO}_{4}(\mathrm{p}), \mathrm{NH}_{4} \mathrm{OH} 12 \%, \mathrm{NaOH} 1 \%$, kapur sirih, akuades, bahan pewarna kimia ponceau GRB dan benang ulos.

Alat yang digunakan pada penelitian ini adalah peralatan gelas seperti labu ukur, batang pengaduk, pipet volume, tabung reaksi, gelas ukur, timbangan analitik merk Matrix, hot plate, corong, cawan, saringan, ember, wadah hasil maserasi dan wadah pasta indigo, $\mathrm{pH}$ Indikator Universal dan pengujian warna dengan Spektronic-20.

\section{Pembuatan larutan}

Pembuatan larutan $\mathrm{NaOH} 1 \%$, sebanyak 10 gram $\mathrm{NaOH}$ dilarutkan dalam labu ukur $1000 \mathrm{~mL}$ dengan akuades dan dipenuhkan sampai tanda batas.

Pembuatan pasta ekstrak daun salaon

\section{Ekstraksi}

Sebanyak $4 \mathrm{Kg}$ daun salaon (Indigofera tinctoria L) segar dipisahkan dari tangkainya, dicuci bersih dan direndam dalam air bersih (fermentasi) 
selama 48 jam pada suhu kamar, di dalam ember yang diberi pemberat. Volume air yang digunakan sebanyak $7 \mathrm{~L}$ untuk $1 \mathrm{Kg}$ daun salaon.

\section{Proses Pengeburan}

Daun salaon dikeluarkan dari air rendaman, kemudian disaring dan dilakukan pengeburan dengan mengambil larutan sedikit demi sedikit dan diangkat ke udara untuk mendapatkan oksigen sehingga terjadi proses oksidasi sampai warna buih putih hilang dan menjadi buih biru. Selanjutnya ke dalam larutan ditambahkan kapur sirih sebanyak 40 gram untuk 1 L larutan rendaman daun salaon. Warna larutan daun salaon setelah dicampur dengan kapur sirih berubah menjadi warna hijau kekuningan. Selanjutnya terhadap larutan dilakukan proses pengeburan dengan mengambil larutan sedikit demi sedikit dan diangkat ke udara untuk mendapatkan oksigen sehingga terjadi proses oksidasi sampai warna buih putih hijau hilang dan berubah menjadi buih biru dan larutan zat warna indigo mengendap menjadi biru gelap (Suheryanto, 2012).

\section{Pengendapan}

Proses pengendapan larutan indigo dilakukan selama 10 jam hingga terjadi endapan biru indigo, dengan warna kuning jerami pada bagian atas. Indigo mulai mengendap dengan pengetesan sebagai berikut: air diambil pada tabung reaksi dilihat ada butiran-butiran biru bergerak turun. Proses pengendapan diteruskan lagi selama 24 jam untuk penyempurnaan pengendapan. Setelah didiamkan selama 24 jam, terbentuk cairan bagian atasnya (warna kuning jerami) dan di bagian bawah terdapat pasta Indigo. Cairan bagian atasnya dibuang dan diperoleh pasta indigo pada bagian bawah. Endapan indigo selanjutnya ditiriskan mengguna-kan kain sampai terjadi pasta indigo yang siap digunakan atau disimpan dalam botol berwarna dan tertutup serta terhindar dari cahaya (Suheryanto, 2012).

Pengukuran absorbansi dan $\mathrm{pH}$ larutan pada proses pembuatan pasta

Pengukuran $\mathrm{pH}$ larutan dan absorbansi pada panjang gelombang $585 \mathrm{~nm}$ dilakukan pada saat sebelum aerasi (pengeburan), setelah aerasi dan sesudah penambahan kapur sirih dengan menggunakan spektronik-20. Setelah itu pasta indigo yang diperoleh disimpan dalam botol berwarna dan tertutup agar terhindar dari cahaya.

\section{Pewarnaan benang ulos}

\section{Pembuatan larutan pewarna}

Pembuatan larutan pewarna dilakukan pada saat akan dilakukan proses pencelupan.

Pewarna salaon

Pasta indigo sebanyak 500 gram dilarutkan dengan air sedikit demi sedikit sampai larut sempurna dengan $5 \mathrm{~L}$ air. Larutan warna didiamkan selama 24 jam hingga terbentuk larutan berwarna hijau olive.

\section{Pewarna kimia}

Pewarna kimia ponceau GRB sebanyak 500 gram dilarutkan dengan air sedikit demi sedikit sampai larut sempurna dengan $5 \mathrm{~L}$ air. Larutan warna didiamkan selama 24 jam hingga menjadi larutan berwarna biru tua.

\section{Proses pencelupan}

Sebelum benang dicelup pada larutan pewarna, benang terlebih dahulu direndam dalam larutan $\mathrm{NaOH} 1 \%$ selama 3 menit, ditiriskan dan dibilas dengan akuades. Selanjutnya sediakan dua buah wadah pencelupan untuk pewarna pasta ekstrak daun salaon dan pewarna kimia. Proses pencelupan benang dilakukan ulangan tiga kali.

Wadah pewarna ekstrak daun salaon

Pencelupan dimulai selama 15 menit, diangkat, ditiriskan dan diangin-anginkan untuk mendapatkan oksidasi udara (aerasi) sehingga terjadi perubahan warna dari kuning hijau berangsur-angsur menjadi biru. Setelah warna biru rata, benang dicuci kedalam ember atau air mengalir supaya endapan kapur (latak) hilang dan ditiriskan lagi sampai agak kering. Pencelupan diulangi sampai 3 kali hingga warna merata pada benang.

\section{Wadah pewarna kimia}

Untuk pewarna kimia pencelupan dimulai selama 15 menit, diangkat, ditiriskan dan dianginanginkan sampai benang berwarna biru. Pencelupan diulang sampai 3 kali, sehingga warna merata pada benang kemudian dicuci dan dikeringkan.

\section{Analisis kualitas warna dan benang ulos hasil pewarnaan \\ Analisis kualitas warna dan benang ulos yang} telah diwarnai dengan pewarna alami pasta ekstrak daun salaon dan pewarna kimia meliputi daya tahan luntur terhadap pencucian sabun, terhadap sinar matahari, dan penomoran benang (Tex) dilakukan sesuai dengan standar SNI ISO 105-X12 (Anonim, 2010) di Laboratorium Evaluasi Tekstil Jurusan Tehnik Kimia, Fakultas Teknologi Industri, Universitas Islam Indonesia. 


\section{Hasil dan Pembahasan}

Pembuatan pasta ekstrak daun salaon

\section{Ekstraksi}

Hasil proses ekstraksi dari 4,0 kg daun salaon diperoleh sebanyak 28 L larutan ekstrak.

\section{Aerasi dan pengendapan}

Hasil ekstraksi atau hasil dari ekstraksi disebut ekstrak (Simorangkir, 2017) daun salaon setelah ditambahkan kapur sirih $\mathrm{Ca}(\mathrm{OH})_{2}$ sebanyak 40 gram untuk 1 L larutan ekstrak pada proses aerasi dan pengendapan, diperoleh rendemen pasta indigo berwarna biru sebesar 31,2\%.

Nilai $\mathrm{pH}$ dan absorbansi larutan pada proses pembuatan pasta daun salaon

Nilai pH dan absorbansi larutan selama proses pembuatan pasta daun salaon ditunjukkan pada Tabel 1.

Tabel 1

Nilai pH dan absorbansi larutan pasta daun salaon

\begin{tabular}{cllcc}
\hline No & Proses & Absorbansi & $\% \mathrm{~T}$ & $\mathrm{pH}$ \\
\hline 1 & $\begin{array}{l}\text { Sebelum } \\
\text { pengeburan }\end{array}$ & 2,0686 & $0,09 \%$ & 8 \\
2 & $\begin{array}{l}\text { Setelah } \\
\text { pengeburan }\end{array}$ & 2,0975 & $0,08 \%$ & 7 \\
3 & $\begin{array}{l}\text { Setelah } \\
\text { penambahan } \\
\text { kapur }\end{array}$ & 3,0105 & $0,01 \%$ & 8 \\
\hline
\end{tabular}

Nilai absorbansi larutan zat warna pasta daun salaon, sebelum dan sesudah diaerasi/ pengeburan serta setelah ditambah kapur sirih semakin tinggi yang menunjukkan bahwa semakin banyak zat warna yang terlarut dalam larutan pasta ekstrak daun salaon (Tabel 1). Nilai $\mathrm{pH}$ larutan 8 menunjukkan proses aerasi atau oksidasi indoksil berlangsung dalam suasana basa. Hal ini sesuai dengan penelitian yang dilakukan oleh Suheryanto (2012).

Sebelum dilakukan pencelupan warna, terlebih dahulu dilakukan perendaman benang ulos dalam larutan $\mathrm{NaOH} 1 \%$ untuk membuat benang dalam suasana basa sehingga selulosa pada benang mengembang dan zat warna dapat masuk dan terikat pada serat benang. Setelah proses pewarnaan benang ulos dengan zat warna alami pasta ekstrak daun Salaon (Indigofera tinctoria $L$ ) dan pewarna kimia, dilakukan pengujian kualitas warna dan benang ulos.

Hasil uji kualitas warna dan benang ulos hasil pewarnaan

Hasil pengujian kualitas warna dan benang ulos, meliputi ketahanan luntur terhadap pencucian rumah tangga, ketahanan luntur terhadap penyinaran (sinar matahari) dan penomoran benang (Tex) sesuai dengan standar SNI ISO 105 X12 (Anonim, 2010) seperti ditunjukkan pada Tabel 2.

\section{Tabel 2}

Hasil uji kualitas warna dan benang ulos hasil pewarnaan salaon dan kimia

\begin{tabular}{|c|c|c|c|}
\hline $\begin{array}{c}\text { Kode } \\
\text { sampel }\end{array}$ & $\begin{array}{l}\text { Nilai uji } \\
\text { terhadap } \\
\text { pencucian } \\
\text { sabun }\end{array}$ & $\begin{array}{l}\text { Nilai uji } \\
\text { terhadap } \\
\text { sinar } \\
\text { matahari }\end{array}$ & $\begin{array}{l}\text { Nilai uji } \\
\text { penomoran } \\
\text { benang }\end{array}$ \\
\hline$A$ & 4 & $4-5$ & 43,68 \\
\hline Salaon & Baik & Baik & \\
\hline B & $3-4$ & $3-4$ & 38,21 \\
\hline $\begin{array}{l}\text { Pewarna } \\
\text { kimia }\end{array}$ & Cukup baik & Cukup baik & \\
\hline
\end{tabular}

Hasil uji kualitas warna dari benang ulos menunjukkan bahwa pewarna alami pasta ekstrak daun salaon lebih baik dengan nilai daya tahan luntur pencucian 4 (baik), terhadap penyinaran 4-5 (baik) dibandingkan dengan pewarna kimia ponceau GRB dengan nilai daya tahan luntur pencucian 3-4 (cukup), terhadap penyinaran 3-4 (cukup). Pewarnaan dengan zat warna alami indigo memiliki hasil ketahanan luntur yang baik daripada pewarna kimia. Hasil analisis FT-IR zat warna alami pasta ekstrak daun salaon disajikan pada Gbr 3.

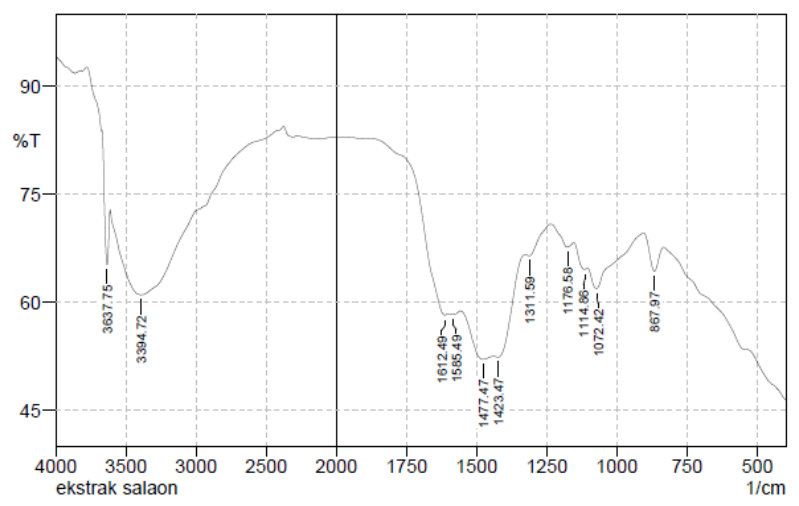

Gbr 3. Spektra FT-IR sampel zat warna indigo pasta ekstrak daun salaon

Berdasarkan data spektra IR (Gbr 3), diduga senyawa yang terdapat pada pewarna alami pasta ekstrak daun salaon adalah senyawa leuco indigo dengan interpretasi berikut: adanya serapan lebar dan kuat pada $3300 \mathrm{~cm}^{-1}$ adalah rentangan $\mathrm{N}-\mathrm{H}$, serapan tajam dan kuat pada sekitar $3600 \mathrm{~cm}^{-1}$ adalah rentangan $\mathrm{C}-\mathrm{H}\left(\mathrm{sp}^{3}-\mathrm{s}\right)$ dari metil dan metilen $\left(\mathrm{CH}_{2}\right)$, serapan lemah sekitar $1600 \mathrm{~cm}^{-1}$ adalah alkena, sedangkan serapan lemah $1450 \mathrm{~cm}^{-1}$ adalah rentangan aromatis dan 
sekitar $1300 \mathrm{~cm}^{-1}-1000 \mathrm{~cm}^{-1}$ adalah karbonil $\mathrm{C}=0$ (Sitorus, 2009).

Pewarnaan dengan zat warna alami indigo memiliki hasil ketahanan luntur yang lebih baik daripada pewarna kimia. Pewarnaan dengan zat warna alami indigo memiliki hasil pewarnaan yang lebih baik karena zat warna alami indigo saat masuk ke dalam serat kain dan dioksidasi yang awalnya zat indigo merupakan zat indigo terdispersi berubah menjadi molekul besar yang tidak mudah keluar dari serat sehingga semakin tinggi ketahanan lunturnya yang mengakibatkan kualitas benang ulos dan ulos yang diwarnai semakin bagus. Pasta ekstrak daun salaon dapat digunakan sebagai alternative pewarna alami kain tenun ulos yang berkualitas. Pembuatan bentuk sediaan pasta ekstrak daun salaon yang dapat disimpan dan digunakan pada saat diperlukan dapat dipertimbangkan oleh pengrajin ulos untuk kembali menggunakan bahan pewarna alami salaon. Ulos "Sibolang" yang menggunakan pewarna alami indigo pasta ekstrak daun salaon disajikan pada Gbr 4. Ulos "Sibolang" merupakan jenis ulos yang digunakan pada waktu acara dukacita/kematian adat Batak.

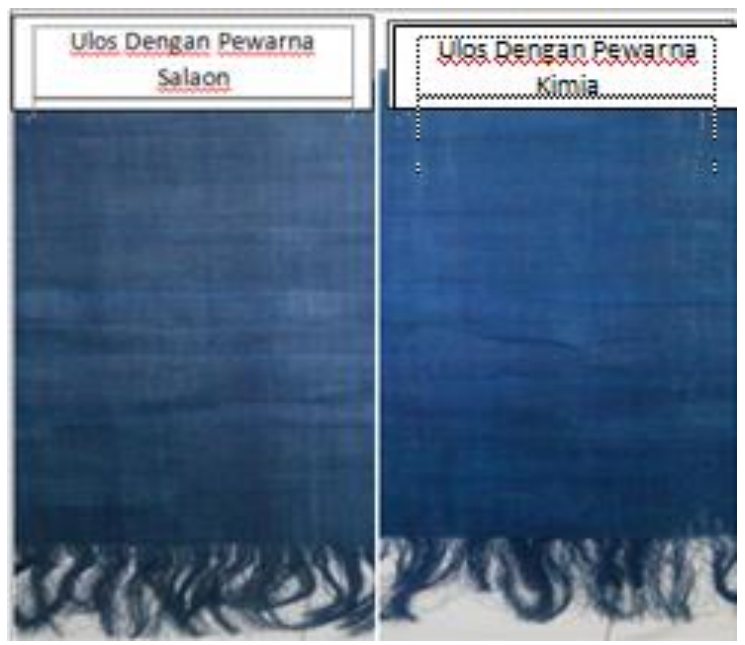

Gbr 4. Ulos "sibolang" menggunakan pewarna indigo pasta eksrak daun salaon dan pewarna kimia

Hasil Penelitian Suheryanto (2012) melaporkan bahwa penggunaan pewarna alami indigo dari daun Indogofera tinctoria pada pewarnaan kain sutera dan katun menghasilkan uji tahan luntur terhadap pencucian 4-5 (baik) dan uji terhadap penyinaran 4 (baik) dan terhadap tahan gosokan 3-4 (cukup). Hasil penelitian Kusumawati et al., (2016) juga melaporkan bahwa penggunaan pewarna $25 \%$ indigo menunjukkan kualitas kulit (serat kolagen) ikan bandeng yang terbaik. Hasil analisis FT-IR zat warna kimia ponceau RGB disajikan pada Gbr 5 .

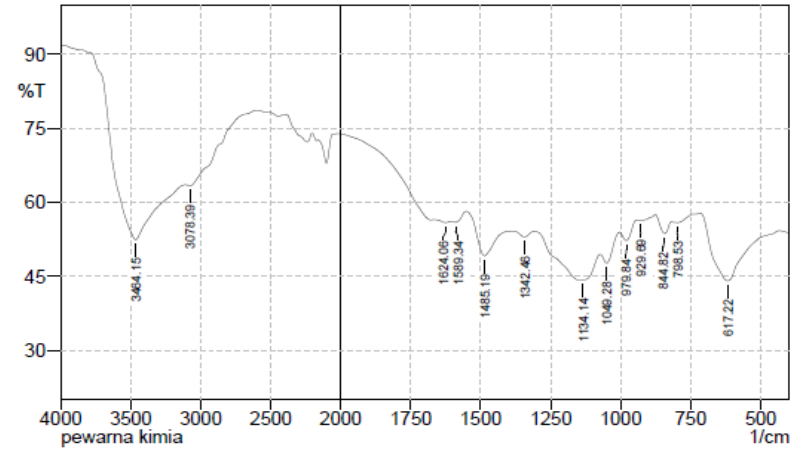

Gbr 5. Spektra FT-IR sampel zat warnakimia ponceau RGB

Berdasarkan spektra Gambar 5, zat pewarna kimia ponceau RGB diinterpretasikan dengan serapan kuat dan lebar pada $3500 \mathrm{~cm}^{-1}-3200$ $\mathrm{cm}^{-1}$ adalah rentangan $\mathrm{OH}$ yang diperkuat oleh rentangan C-O pada $1050 \mathrm{~cm}^{-1}$. Serapan sekitar 3600 adalah $\mathrm{C}-\mathrm{H}\left(\mathrm{sp}^{3} \mathrm{-s}\right)$ dari $\left(\mathrm{CH}_{2}\right)$ metil dan metilen (Sitorus, 2009).

\section{Kesimpulan}

Pasta ekstrak daun salaon (Indigofera tinctoria L) yang mengandung senyawa leuco indigo dapat digunakan sebagai pewarna alami kain tenun ulos yang mempunyai kualitas daya tahan luntur, penyinaran dan kualitas benang yang lebih baik dibandingkan pewarna kimia ponceau GRB.

\section{Ucapan Terima Kasih}

Ucapan terima kasih ditujukan kepada Kemenristekdikti yang telah memberikan dana penelitian PKMP dengan surat perjaniian nomor: 547/B3.1/KM/2017 dan jurusan Kimia FMIPA Universitas Negeri Medan yang telah menyediakan fasilitas dalam pelaksanaan penelitian ini.

\section{Daftar Pustaka}

Anonim. (2014). Perajin Ulos. (diakses 25 Juni 2017) https://tanobatak.wordpress.com/

Anonim. (2010). Standar industri Indonesia. cara uii tekstil. SNI ISO 105-A02-2010. dan SNI ISO 105-A03-2010. Balai Besar Penelitian dan Pengembangan Industri Tekstil. Bandung.

Kim, J.Y., Lee, J.Y., Shin, Y.S. \& Kim, G.J. (2009). Mining and identification of a glucosidase family enzyme with high activity toward the plant extract indican. Journal of Moleculer Catalysis B. Enzymatic, 57:284-291. 
Kumar, A.S.R., Gandhimathi, L.S., Mohana, N., \& Rahul, K.C.K. (2009). Evaluation of the antinociceptive properties from Indigofera tinctoria L extracts. Sree Vidyanikethan College of Pharmacy. Sree Sainath Nagar. Chandragiri (M). Tirupati. Andhara Pradesh. India. Journal of Pharmaceutical Sciences and Research, 1:31-37.

Kusumawati, F., Riyadi, R.H. \& Rianingsih, L. (2016). Applications indigo (Indigofera tinctoria L.) as natural dyeing in milkfish [Chanos chanos (Forsskal, 1775)] Skin Tanning Process. 2nd International symposium on aquatic products processing and health ISAPPROSH. Aquatic Procedia, 7:92-99.

Her. \& Eka. (2002). Teknologi pewarna alam. balai besar penelitian dan pengembangan industri kerajinan dan batik. Yogyakarta.

Lestari, K.W.F. (1998). Dyeing process with natural indigo: The tradition and technology, Revival Natural Indigo dye. Sept 20-29.

Laitonjam, W.S. \& Wangkheirakpam, S.D. (2011). Comparative study of the major components of the indigo dye obtained from Strobilanthes flaccidifolius Nees. and Indigofera tinctoria Linn. International Journal of Plant Physiology and Biochemistry, 3:108-116.

Simorangkir, M., Surbakti, R., Barus, T. \& Simanjuntak, P. (2017). Analisis fitokimia metabolit sekunder ekstrak daun dan buah (Solanum blume Nees ex Blume) lokal. Jurnal Pendidika Kimia (JPKim), 9:244-248.

Sitorus, M. (2009). Spektroskopi elusidasi struktur molekul organik. Graha Ilmu: Medan.

Suheryanto, D. (2012). Optimasi waktu fermentasi pembuatan zat warna alam indigo (Indigofera tinctorria). Teknik Kimia UPN, Surabaya. 